\title{
Kodamaea nitidulidarum, Candida restingae and Kodamaea anthophila, three new related yeast species from ephemeral flowers
}

\author{
Carlos A. Rosa, ${ }^{1}$ Marc-André Lachance, ${ }^{2}$ William T. Starmer, ${ }^{3}$ \\ J. Stuart F. Barker, ${ }^{4}$ Jane M. Bowles ${ }^{2}$ and Birgit Schlag-Edler ${ }^{2}$
} Author for correspondence: Marc-André Lachance. Tel: +1 519661 3752. Fax : +1 5196613935.
e-mail: lachance@julian.uwo.ca

\footnotetext{
1 Departamento de Microbiologia - ICB, Universidade Federal de Minas Gerais, Belo Horizonte, MG, CEP 31270-901, Brazil

2 Department of Plant Sciences, University of Western Ontario, London, Ontario, Canada N6A 5B7

3 Department of Biology, Syracuse University, Syracuse, NY 13244, USA

4 Department of Animal Science, University of New England, Armidale, NSW 2351, Australia
}

\begin{abstract}
Three new yeast species were discovered during studies of yeasts associated with ephemeral flowers in Brazil, Australia and Hawaii. Their physiological and morphological similarity to Kodamaea (Pichia) ohmeri suggested a possible relationship to that species, which was confirmed by rDNA sequencing. Kodamaea nitidulidarum and Candida restingae were found in cactus flowers and associated nitidulid beetles in sand dune ecosystems (restinga) of Southeastern Brazil. Over $\mathbf{3 5 0}$ strains of Kodamaea anthophila were isolated from Hibiscus and morning glory flowers (Ipomoea spp.) in Australia, and from associated nitidulid beetles and Drosophila hibisci. A single isolate came from a beach morning glory in Hawaii. Expansion of the genus Kodamaea to three species modified the existing definition of the genus only slightly. The type and isotype strains are as follows: $K$. nitidulidarum strains UFMG96-272 ${ }^{\top}\left(\mathrm{h}^{+}\right.$; CBS 8491') and UFMG96-394' ( $\mathrm{h}^{-}$; CBS 8492'); Candida restingae UFMG96-276' (CBS 8493'); $K$. anthophila strains UWO(PS)95-602.1' (h'; CBS 8494'), UWO(PS)91-893.2' (h'; CBS 8495') and UWO(PS)95-725.1' (h-; CBS 8496').
\end{abstract}

Keywords: Kodamaea, new yeast species, nitidulid beetles, Hibiscus, Ipomoea

\section{INTRODUCTION}

Pichia ohmeri (Etchells \& Bell) Kreger-van Rij was first described as Endomycopsis ohmeri and later transferred to the genus Pichia Hansen (Kreger-van Rij, 1970). This yeast species is heterothallic, normally isolated in the haploid form, and, depending upon the mating types paired, ascospores may be either hat-shaped or spheroidal (Kurtzman, 1984). Billon-Grand (1989) introduced the new genus Yamadazyma Billon-Grand to accommodate 16 species from the genus Pichia, including Pichia ohmeri (Yamadazyma ohmeri). Yamada et al. (1995a), on the basis of rRNA sequences, concluded that $Y$. ohmeri was not closely related to any other species of either Pichia or Yamadazyma. Accordingly, the genus Kodamaea Yamada, Suzuki, Matsuda \& Mikata was proposed for that species (Yamada et al., 1995b).

In the course of studies of yeast communities as-

The GenBank accession numbers for the sequences in this paper are AF059665-AF059669. sociated with decaying cactus flowers in South-eastern Brazil, and Hibiscus and morning glory flowers in Australia and Hawaii, two heterothallic haploid and one anascosporogenous species were isolated that appeared physiologically similar to Kodamaea ohmeri. One species previously referred to as 'Pichia sp. A' (Rosa et al., 1994) was isolated from flowers of the cactus Pilosocereus arrabidae and from an unidentified beetle in the family Nitidulidae that uses these flowers as feeding and breeding sites. The beetle was thought to be the principal vector of 'Pichia sp. A' among cactus flowers in sand dune ecosystems in Brazil. Another new yeast species ('Candida sp. C'; Rosa et al., 1995) was found in cactus flowers in the same area. This species was asporogenous but physiologically similar to K. ohmeri and 'Pichia sp. A'. A third species was found in Australian Hibiscus and morning glory flowers, a Hawaiian morning glory, as well as in Drosophila hibisci and various nitidulid beetles found in the Australian flowers. In this paper, we describe Kodamaea nitidulidarum, Candida restingae and Kodamaea anthophila, and discuss their relatedness to $K$. ohmeri. 


\section{METHODS}

Isolation and characterization of yeasts. The origin of the strains considered in this study is described in Tables 1,2 and 3. Strains of $K$. nitidulidarum and Candida restingae were isolated from decaying flowers of the cacti $P$. arrabidae and Cereus pernanbucensis, and from tunnels of larvae of the moth Sigelgaita sp. in sand dune ecosystems of Southeastern Brazil in 1996. The methods used for yeast isolation were described by Rosa et al. $(1994,1995)$. The first isolations from Australian Hibiscus were performed in 1990 in a pilot study of the ecology of insects and yeasts associated with these flowers. Several hundred samples of Hibiscus and morning glory were collected in late spring 1995 over a 6week period, across a $14^{\circ}$ latitude gradient, mostly in the vicinity of the Australian East Coast. Beach morning glory (Ipomoea pes-caprae) flowers were collected in Hapuna Beach, near Waimea, Hawaii Island, in 1991. Yeasts were cultured the same day, usually within minutes of sampling. The nectary region of flowers was scraped gently with a sterile loop and streak-inoculated onto acidified YM agar ( $1.0 \%$ glucose, $0.5 \%$ peptone, $0.3 \%$ malt extract, $0.3 \%$ yeast extract, $2 \cdot 0 \%$ agar, acidified with $\mathrm{HCl}$ to $\mathrm{pH} 3.7$ ). Drosophila or beetles were placed in plates of the same medium and kept for 15-60 min before being removed. The material deposited by the insects was spread evenly with a sterile loop. Cultures were maintained in YM slants until preserved in liquid nitrogen using the Microbank system of Pro-Lab diagnostics.

The yeasts were characterized by standard methods (van der Walt \& Yarrow, 1984), with some additional tests (Lachance et al., 1988). Identities were verified in the keys of Kregervan Rij (1984) and Barnett et al. (1990). Phenetic similarity with other described yeasts was examined with the computer program IDENT (M.-A. Lachance, unpublished), which compares the nutritional characteristics of any yeast with those of known species. The database was initially taken from Barnett et al. (1990) and updated as appropriate. Sexual cross-reactivity was evaluated by mixing pairs of actively growing cultures on GY agar (1.0\% glucose, $0.01 \%$ yeast extract and $2.0 \%$ agar), and observing microscopically for signs of conjugation or ascus formation daily during a week.

Scanning electron microscopy. Materials were suspended in sterile water and deposited over a Nuclepore membrane $(0.45 \mu \mathrm{m})$ on agar. In the case of $K$. nitidulidarum the ascospores were released by digestion for $3 \mathrm{~h}$ with Mureinase (US Biochemical) in $10 \mathrm{mM}$ sodium succinate buffer, $\mathrm{pH} 5 \cdot 8$, prior to fixation. The membrane and its content were fixed in $2.5 \%$ glutaraldehyde in $0.3 \mathrm{M}$ cacodylate buffer, $\mathrm{pH} 7 \cdot 0$, for at least $15 \mathrm{~min}$, rinsed twice in cacodylate buffer and dehydrated for $15 \mathrm{~min}$ in 2,2-dimethoxypropane lightly acidified with $\mathrm{HCl}$. The material was then critical point dried, sputter-coated with gold for $5 \mathrm{~min}$, and observed with a Hitachi S4500 Field Emission scanning electron microscope (Surface Science Western). Images were recorded electronically.

Electrophoretic karyotyping. Karyotypes were obtained using contour-clamped homogeneous electric field electrophoresis (Bio-Rad CHEF DRII). Intact chromosomes were prepared according to the method of Gardner et al. (1993).

Table 1. Origin of the strains of $K$. nitidulidarum in sand dune ecosystems of Rio de Janeiro State, Brazil

The host plant was $P$. arrabidae.

\begin{tabular}{|llll|}
\hline Locality & Substrate type & $\begin{array}{c}\text { Mating } \\
\text { type }\end{array}$ & Strain no. (UFMG) \\
\hline Arraial do Cabo & Flower & $\mathrm{h}^{+}$ & $96-353$ \\
& Sigelgaita sp. tunnel & $\mathrm{h}^{-}$ & $96-394^{1}, 96-352$ \\
& Flower & $\mathrm{h}^{+}$ & $96-340$ \\
Maricá & & $\mathrm{h}^{-}$ & $96-272^{\mathrm{T}}, 96-328$ \\
& Sigelgaita sp. tunnel & $\mathrm{h}^{-}$ & $96-305,96-329$ \\
Praia Seca & Flower & $\mathrm{h}^{+}$ & $96-319$ \\
\hline
\end{tabular}

Table 2. Host plants and geographic origins of the strains of Candida restingae in sand dune ecosystems of Rio de Janeiro State, Brazil

\begin{tabular}{|llll|}
\hline Host plant & \multicolumn{1}{c}{ Locality } & Substrate type & Strain no. (UFMG) \\
\hline \multirow{2}{*}{ Cereus pernambucensis } & Arraial do Cabo & Flower & $96-276^{\mathrm{T}}$ \\
& Praia Seca & Flower & $96-380$ \\
Pilosocereus arrabidae & Arraial do Cabo & Flower & $96-331$ \\
& Maricá & Flower & $96-271$ \\
& & Sigelgaita sp. tunnel & $96-308,96-322$ \\
& Praia Seca & Sigelgaita sp. tunnel & $96-274$ \\
\hline
\end{tabular}


Electrophoresis was carried out in a $0 \cdot 8 \%(\mathrm{w} / \mathrm{v})$ agarose gel in $1 \times$ TBE buffer under the following conditions: $110 \mathrm{~V}$, $24 \mathrm{~h}$ with linear ramping of $100-300 \mathrm{~s}$ and $28 \mathrm{~h}$ with linear ramping of $400-700 \mathrm{~s}$.

DNA sequence analysis. DNA was extracted as described previously (Lachance, 1990). The D1 and D2 variable domains of the large-subunit rDNA were amplified using primers NLl (5' GCATATCAATAAGCGGAGGAAAAG) and NL4 (5' GGTCCGTGTTTCAAGACGG; O'Donnell, 1993), purchased from Procyon Biopharma. The PCR was conducted following the instructions provided by the supplier of Taq polymerase (Boehringer Mannheim), in the presence of $1.5 \mathrm{mM} \mathrm{MgCl}$, in a Perkin-Elmer System 2400 cycler. After $2 \mathrm{~min}$ denaturation at $95^{\circ} \mathrm{C}$, the mixture was subjected to 35 cycles at $95^{\circ} \mathrm{C}$ for $15 \mathrm{~s}, 53.7^{\circ} \mathrm{C}$ for $25 \mathrm{~s}$ and $72^{\circ} \mathrm{C}$ for $20 \mathrm{~s}$, with a final extension for $5 \mathrm{~min}$ at $72{ }^{\circ} \mathrm{C}$. The amplified DNA was concentrated and cleaned by ultrafiltration in MicroCon 100 concentrators (Amicon) and sequenced in an ABI sequencer at the John P. Robarts Research Institute, London, Ontario. The sequences were edited with the program DNAMAN, version 3.2 (Lynnon BioSoft). Existing sequences for other yeasts (Kurtzman \& Robnett, 1997) were retrieved from GenBank. The CLUSTAL w (Thompson et al., 1994) algorithm provided in the DNAMAN package was used to align the sequences and construct a neighbour-joining tree with 1000 bootstrap iterations.

\section{RESULTS AND DISCUSSION}

\section{Latin diagnosis of Kodamaea nitidulidarum sp. nov.}

In medio liquido post dies tres cellulae singulae, binae, aut in catenis brevis, ovoidae $(1-3 \times 3-6 \mu \mathrm{m})$. Cellulae cum extuberatione formari possunt. Post unum mensem sedimentum formatur. Cultura in agaro malti post dies $14\left(17^{\circ} \mathrm{C}\right)$, tumulosa, aliquando cum lineis radialibus, glabra aut rugosa, candida, butyrosa aut firma. In agaro farinae Zea mays post dies 14 mycelium verum formatur. Post dies unum, cellulae stirpum interfertilium mixtarum in agaro glucosi et extracti levidinis tubi junctionis formantur. Post dies tres, asci conjugati possunt videri. Asci stabiles sunt. Ascosporae petasosae. Glucosum (lente) fermentatur. Sucrosum, raffinosum, galactosum, maltosum, melezitosum, methyl $\alpha$-D-glucosidum, cellobiosum (exigue et lente), salicinum (lente), L-sorbosum, D-arabinosum (variabile et exigue), ethanolum (lente), glycerolum (variabile et exigue), ribitolum (lente), mannitolum, glucitolum, acidum succinicum (exigue), acidum citricum, 2-ketogluconatum, glucosaminum (exigue), $N$-acetylglucosaminum et hexadecanum (exigue) assimilantur at non inulinum, melibiosum, lactosum, trehalosum, amylum solubile, L-rhamnosum, $D$-xylosum L-arabinosum, D-ribosum, methanolum, 1-propanolum, 2-propanolum, 1-butanolum, erythritolum, xylitolum (aliquando exigue), galactitolum, mesoinositolum, acidum lacticum, acidum malicum, acidum gluconicum, glucono- $\delta$-lactonum (aliquando exigue), acetonum, nec ethyl acetas. Ethylaminum (lente), lysinum et cadaverinum assimilantur at non natrium nitricum nec natrium nitrosum. Ad crescentiam vitaminae externae necessariae sunt. Augmentum in $37^{\circ} \mathrm{C}$. Habitatio in floribus Pilosocereus arrabidae et in scarabeis junctis Nititulidae in Brasil. Typus UFMG96-272 ${ }^{\mathrm{T}}\left(\mathrm{h}^{+}\right)$. Isotypus UFMG96-394 ${ }^{\mathrm{I}}\left(\mathrm{h}^{-}\right)$. In collectione zymotica Centraalbureau voor Schimmelcultures, Delphi Batavorum, sub no. CBS $8491^{\mathrm{T}}$ [= UFMG96-272 ] et CBS $8492^{1}$ [ = UFMG96-394'] depositae sunt.

\section{Description of Kodamaea nitidulidarum sp. nov.}

Kodamaea nitidulidarum (ni.ti.du.li.da'rum. L. gen. plur. masc. n. nitidulidarum of nitidulidae, referring to the family of beetles that vector this yeast species).

In yeast extract $(0.5 \%)$ /glucose $(2 \%)$ broth after $3 \mathrm{~d}$ at $25^{\circ} \mathrm{C}$, the cells are ovoid to ellipsoidal, occur singly, in parent-bud pairs, or occasionally in short chains, and measure 1-3 $\times 3-6 \mu \mathrm{m}$. Buds may be formed on a short protuberance. A sediment is formed after a month. On malt agar after 2 weeks at $17^{\circ} \mathrm{C}$, colonies are umbonate, sometimes fringed, glabrous, smooth or rugose, white, and butyrous to tough due to filamentous growth. In Dalmau plate cultures on cornmeal agar after 2 weeks true hyphae are formed. After $1 \mathrm{~d}$ on glucose $(1 \%) /$ yeast extract $(0.01 \%)$, mixed strains of complementary mating types give rise to short conjugation tubes. Conjugated pairs and zygotes are also present. Conjugation often occurs between an elongate cell and a more globose cell (Fig. 1d) that develops into the ascus. After $3 \mathrm{~d}$, mature asci are visible. Two to four hat-shaped ascospores are formed. Evanescence is not observed even after prolonged incubation. Fermentation: in glucose, gas production begins after 3-5 d and a full tube of gas develops after 6-10 d. Assimilation of carbon compounds: sucrose, raffinose, galactose, maltose, melezitose, methyl $\alpha$-Dglucoside, cellobiose (slow and weak), salicin (slow), Lsorbose, D-arabinose (variable and weak), ethanol (slow), glycerol (weak and slow), ribitol (slow), mannitol, glucitol, succinic acid (weak), citric acid, 2ketogluconic acid, D-glucosamine (weak), $\mathrm{N}$-acetylglucosamine and hexadecane (weak) are assimilated; no growth occurs on inulin, melibiose, lactose, trehalose, starch, L-rhamnose, D-xylose, L-arabinose, Dribose, methanol, 2-propanol, 1-butanol, erythritol, xylitol (rarely weak), galactitol, meso-inositol, lactic acid, malic acid, D-gluconic acid, glucono- $\delta$-lactone (rarely weak), acetone or ethyl acetate. Assimilation of nitrogen compounds: ethylamine (slow), lysine and cadaverine positive; sodium nitrate and sodium nitrite negative. Growth in vitamin-free medium is negative. Growth in amino-acid-free medium is positive. Growth at $37^{\circ} \mathrm{C}$ is positive. Gelatin liquefaction and casein hydrolysis are negative. Lipolytic activity on Tween 80 agar is positive. Acid formation on chalk agar is negative. Growth on YM agar with $10 \%$ sodium chloride is positive; with $15 \%$ sodium chloride it is negative. Growth on $50 \%$ glucose/yeast extract agar is slow. Growth in the presence of $10 \mu \mathrm{g}$ cycloheximide $\mathrm{ml}^{-1}$ is negative. Growth in the presence of $8 \mu \mathrm{g}$ digitonin $\mathrm{ml}^{-1}$ at $25^{\circ} \mathrm{C}$ is negative. Production of starch-like compounds is negative. Urease activity is negative. Diazonium Blue $B$ reaction is negative. The 
Table 3. Isolation sources of $K$. anthophila

The numbers of isolates of each mating type $\left(\mathrm{h}^{+} / \mathrm{h}^{-}\right)$are indicated. UWO(PS) strain numbers are given for reference strains only.

\begin{tabular}{|c|c|c|c|c|}
\hline \multirow[t]{2}{*}{ Locality } & \multirow[t]{2}{*}{ Host species } & \multicolumn{3}{|c|}{ Substrate type } \\
\hline & & Flower* & Beetle & Drosophila \\
\hline $\begin{array}{l}\text { Hapuna Beach, Hawaii } \\
\text { Island }\end{array}$ & Ipomoea pes-caprae & $\begin{array}{c}1 / 0 \\
91-893.2^{1}\left(h^{-}\right)\end{array}$ & & \\
\hline \multicolumn{5}{|l|}{ Queensland } \\
\hline Conondale & Ipomoea sp. & $\begin{array}{c}2 / 2 \\
95-602.1^{\mathrm{T}}\left(\mathrm{h}^{+}\right)\end{array}$ & $1 / 1$ & \\
\hline $\begin{array}{l}\text { Charlie Moreland State } \\
\text { Forest }\end{array}$ & Hibiscus heterophyllus (white) & $6 / 7$ & $2 / 3$ & $3 / 0$ \\
\hline Bell Bird Creek & Hibiscus heterophyllus (yellow) & $0 / 3$ & $1 / 1$ & $0 / 1$ \\
\hline Noosa River Ferry & $\begin{array}{l}\text { Hibiscus diversifolius } \\
\text { Ipomoea } \mathrm{sp} .\end{array}$ & $\begin{array}{l}2 / 2 \\
1 / 2\end{array}$ & $0 / 1$ & \\
\hline Pile Gully State Forest & Hibiscus heterophyllus (yellow) & $5 / 6$ & $2 / 2$ & $1 / 0$ \\
\hline Rainbow Beach & Ipomoea pes-caprae & $1 / 2$ & $1 / 0$ & \\
\hline Boreen Point & Hibiscus diversifolius & $1 / 1$ & $0 / 1$ & \\
\hline Cooloola National Park & Hibiscus heterophyllus (yellow) & $5 / 6$ & $2 / 1$ & $0 / 1$ \\
\hline Kirks Road & Hibiscus divaricatus & $2 / 1$ & & \\
\hline Goodnight Scrub State & Hibiscus splendens & $2 / 1$ & $1 / 1$ & $1 / 1$ \\
\hline Forest & & $95-725.1^{\mathrm{I}}\left(\mathrm{h}^{-}\right)$ & & \\
\hline Burnett Creek & Hibiscus heterophyllus (yellow) & $2 / 1$ & & \\
\hline \multirow[t]{3}{*}{ Cedars Creek Crossing } & Hibiscus heterophyllus (yellow) & $1 / 2$ & $1 / 0$ & \\
\hline & $\begin{array}{l}\text { Hibiscus heterophyllus } \times \text { Hibiscus } \\
\text { splendens hybrid }\end{array}$ & $0 / 1$ & & \\
\hline & Hibiscus splendens & $1 / 1$ & $1 / 0$ & \\
\hline \multirow[t]{2}{*}{ Moore Park Beach } & Ipomoea sp. & $1 / 2$ & & \\
\hline & Ipomoea pes-caprae & $0 / 1$ & & \\
\hline Manoo & Hibiscus splendens & $1 / 2$ & & \\
\hline Mount Larcom & Hibiscus heterophyllus (yellow) & $0 / 2$ & & $0 / 1$ \\
\hline Rockhampton & Hibiscus tiliaceus & $2 / 2$ & & \\
\hline Byfield State Forest & Hibiscus heterophyllus (yellow) & $0 / 1$ & & $0 / 1$ \\
\hline Byfield National Park & Hibiscus heterophyllus (yellow) & $1 / 0$ & & \\
\hline \multirow[t]{2}{*}{ Yeppoon } & Hibiscus tiliaceus & $0 / 1$ & & \\
\hline & Ipomoea $\mathrm{sp}$ & $1 / 1$ & & \\
\hline The Caves & Hibiscus heterophyllus (yellow) & $0 / 1$ & $0 / 1$ & $1 / 0$ \\
\hline Toolombah Creek & Hibiscus heterophyllus (yellow) & $1 / 0$ & $0 / 1$ & \\
\hline Eungella National Park & Hibiscus heterophyllus (yellow) & $0 / 1$ & & \\
\hline Mount Ossa Road & Hibiscus heterophyllus (yellow) & & & $1 / 0$ \\
\hline \multirow[t]{2}{*}{ Beatrice Creek } & Hibiscus splendens & $1 / 0$ & $1 / 1$ & \\
\hline & Hibiscus heterophyllus (yellow) & $2 / 0$ & $1 / 0$ & \\
\hline Coppabella & Hibiscus divaricatus & $1 / 0$ & & $1 / 1$ \\
\hline \multirow[t]{3}{*}{ Carnarvon National Park } & Hibiscus heterophyllus (yellow) & $1 / 0$ & & \\
\hline & Hibiscus splendens & $1 / 1$ & $2 / 2$ & $0 / 1$ \\
\hline & Hibiscus divaricatus & $0 / 1$ & & \\
\hline Esk turnoff & Hibiscus tiliaceus & $0 / 1$ & & \\
\hline Mount Crosby & Hibiscus heterophyllus (white) & $1 / 1$ & $0 / 1$ & $1 / 1$ \\
\hline \multirow[t]{2}{*}{ Goodna } & Hibiscus splendens & $1 / 0$ & $0 / 1$ & \\
\hline & Ipomoea $\mathrm{sp}$ & $1 / 2$ & & \\
\hline \multicolumn{5}{|l|}{ New South Wales } \\
\hline Tyagarah Road & Hibiscus diversifolius & $1 / 1$ & $1 / 0$ & $0 / 1$ \\
\hline Giro & Hibiscus heterophyllus (white) & $3 / 2$ & $1 / 0$ & $1 / 1$ \\
\hline Martins Creek & Hibiscus heterophyllus (white) & $1 / 0$ & $0 / 1$ & \\
\hline Ourimbah & Ipomoea sp. & $0 / 1$ & $0 / 1$ & \\
\hline
\end{tabular}


Table 3 (cont.)

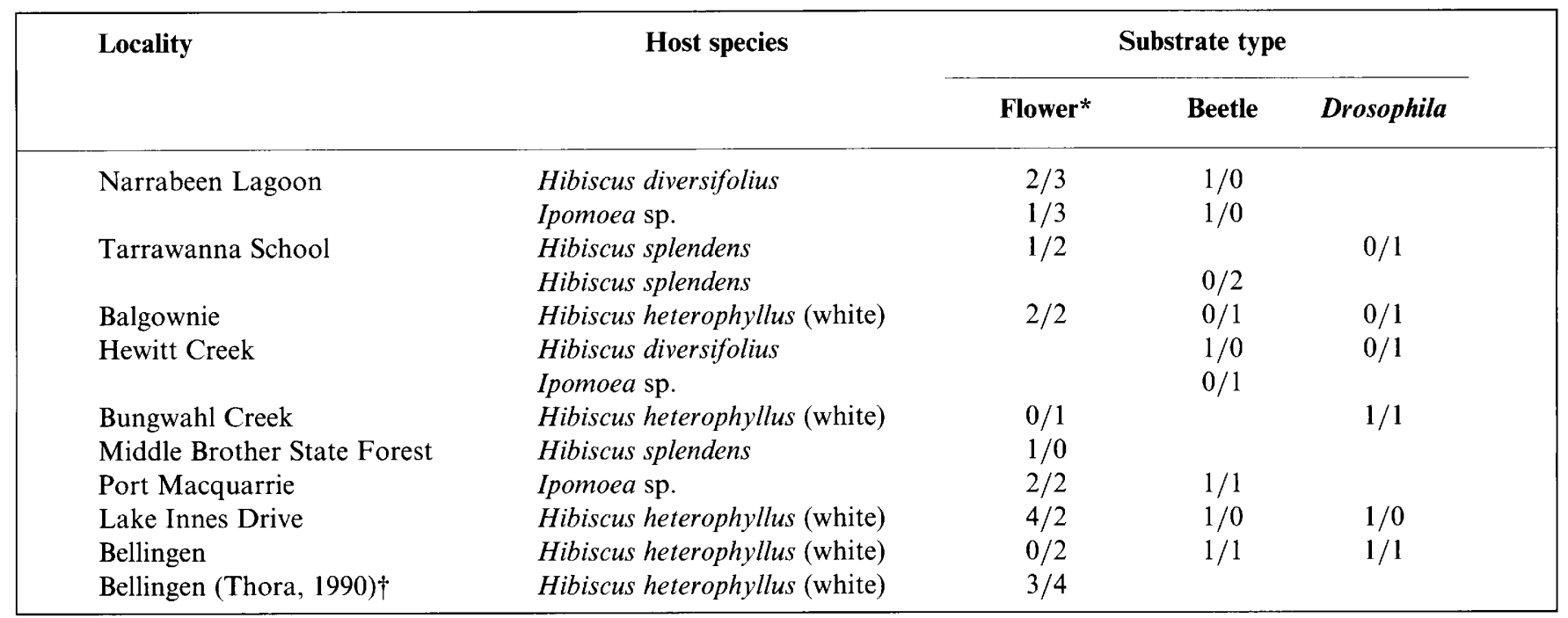

* T, Holotype; I, designated isotypes.

$\dagger$ Thora was the name formerly used to designate the Bellingen site. A preliminary collection was made there in 1990 , whereas the bulk of the work was done in 1995.

habitat is in flowers of Pilosocereus arrabidae and associated nitidulid beetles in sand dune ecosystems in Brazil. The type strain is UFMG96-272 ${ }^{\mathrm{T}}$. Its mating type was designated arbitrarily $\mathbf{h}^{+}$. The designated isotype, strain UFMG96-394 ${ }^{\mathrm{I}}$, has the mating type $\mathrm{h}^{-}$. They were isolated from flowers of Pilosocereus arrabidae in Rio de Janeiro, Brazil. They have been deposited in the collection of the Yeast Division of the Centraalbureau voor Schimmelcultures, Delft, the Netherlands, as strains CBS $8491^{\mathrm{T}}$ and CBS $8492^{\mathrm{I}}$, respectively.

\section{Latin diagnosis of Candida restingae sp. nov.}

In medio liquido post dies tres cellulae singulae aut binae, ovoidae $(2-4 \times 4-6 \mu \mathrm{m})$. Cellulae cum extuberatione formari possunt. Post unum mensem sedimentum formatur. Cultura in agaro malti post dies $14\left(17^{\circ} \mathrm{C}\right)$ infimo-convexa, lucida, candida et butyrosa. In agaro farinae Zea mays post dies 14 hyphae veres formantur. Glucosum (lente) fermentatur. Sucrosum, raffinosum, galactosum, trehalosum (lente), maltosum, melezitosum, methyl $\alpha$-D-glucosidum, cellobiosum (lente), salicinum (lente), L-sorbosum, D-xylosum (lente), ethanolum (lente), glycerolum (lente), ribitolum, xylitolum, mannitolum, glucitolum, acidum succinicum, acidum citricum, acidum malicum (exigue), glucono- $\delta$-lactonum (lente), acidum gluconicum (exigue), 2-ketogluconatum, glucosaminum, $N$-acetylglucosaminum, et hexadecanum (exigue) assimilantur at non inulinum, melibiosum, lactosum, amylum solubile, L-rhamnosum, L-arabinosum, D-arabinosum, D-ribosum, methanolum, 2-propanolum, 1-butanolum, erythritolum, galactitolum, meso-inositolum, acidum lacticum, acetonum, nec ethyl acetas. Ethylaminum, lysinum et cadaverinum assimilantur at non natrium nitricum nec natrium nitrosum. Ad crescentiam vitaminae externae necessariae sunt. Augmentum in $37^{\circ} \mathrm{C}$. Typus stirps UFMG96-276 ${ }^{\mathrm{T}}$. Habitatio in floribus cactorum in Brasil. In collectione zymotica Centraalbureau voor Schimmelcultures, Delphi Batavorum, sub no. CBS $8493^{\mathrm{T}}$ [= UFMG96$276^{\mathrm{T}}$ ] deposita est.

\section{Description of Candida restingae sp. nov.}

Candida restingae (res.tin'gae. $\mathrm{L}$. gen. fem. $\mathrm{n}$. restingae of the restinga, referring to the coastal sand dune ecosystem where this yeast species was isolated).

In yeast extract $(0.5 \%)$ /glucose $(2 \%)$ broth after $3 \mathrm{~d}$ at $25^{\circ} \mathrm{C}$, the cells are ovoid to ellipsoidal, occur singly or in parent-bud pairs, and measure $2-4 \times 4-6 \mu \mathrm{m}$. Buds may be formed on a short protuberance. A sediment is formed after a month. On malt agar after 2 weeks at $17^{\circ} \mathrm{C}$, colonies are small, low convex, glossy, smooth, white and butyrous. In Dalmau plate cultures on cornmeal agar after 2 weeks, some true hyphae are formed. Asci and ascospores are not formed. Fermentation: in glucose, gas production begins after $2-3 \mathrm{~d}$ and a full tube of gas develops after 4-5 d. Assimilation of carbon compounds: sucrose, raffinose, galactose, trehalose (slow), maltose, melezitose, methyl $\alpha$-D-glucoside, cellobiose (slow), salicin (slow), Lsorbose, D-xylose (slow), ethanol (slow), glycerol (slow), ribitol, xylitol, mannitol, glucitol, succinic acid, citric acid, malic acid (weak), glucono- $\delta$-lactone (slow), D-gluconic acid (weak), 2-ketogluconic acid, $\mathrm{N}$ acetylglucosamine and hexadecane (weak) are assimilated; no growth occurs on inulin, melibiose, lactose, starch, L-rhamnose, L-arabinose, D-arabinose, Dribose, methanol, 2-propanol, 1-butanol, erythritol, galactitol, meso-inositol, lactic acid, D-gluconic acid, 
acetone or ethyl acetate. Assimilation of nitrogen compounds: ethylamine, lysine and cadaverine positive; sodium nitrate and sodium nitrite negative. Growth in vitamin-free medium is negative. Growth in amino-acid-free medium is positive. Growth at $37^{\circ} \mathrm{C}$ is positive. Gelatin liquefaction and casein hydrolysis are negative. Lipolytic activity on Tween 80 agar is positive. Acid formation on chalk agar is negative. Growth on YM agar with $10 \%$ sodium chloride is slow; with $15 \%$ sodium chloride it is negative. Growth on $50 \%$ glucose/yeast extract agar is negative. Growth in the presence of $10 \mu \mathrm{g}$ cycloheximide $\mathrm{ml}^{-1}$ is weak; with $100 \mu \mathrm{g} \mathrm{ml}^{-1}$ it is negative. Growth in the presence of $8 \mu \mathrm{g}$ digitonin $\mathrm{ml}^{-1}$ at $25^{\circ} \mathrm{C}$ is negative. Production of starch-like compounds is negative. Urease activity is negative. Diazonium Blue B reaction is negative. The habitat is in flowers of columnar cacti in sand dune ecosystems in Brazil. The type strain is UFMG96$276^{\mathrm{T}}$. It was isolated from a flower of the cactus Cereus pernanbucensis in Brazil. This strain has been deposited in the collection of the Yeast Division of the Centraalbureau voor Schimmelcultures, Delft, the Netherlands, as strain CBS $8493^{\mathrm{T}}$.

\section{Latin diagnosis of Kodamaea anthophila sp. nov.}

In medio liquido post dies tres cellulae singulae aut binae, ovoidae $(2-4 \times 4-6 \mu \mathrm{m})$. Post unum mensem sedimentum et velum rugosum formantur. Cultura in agaro malti post dies $14\left(17^{\circ} \mathrm{C}\right)$, tumulosa, hebes aut rugosa, candida et butyrosa aut firma. Lineis radialibus possunt formari. In agaro farinae Zea mays post dies 14 mycelium verum formatur. Post dies unum, cellulae stirpum interfertilium mixtarum in agaro carbonis fundamento plures tubi junctionis formantur. Post dies tres, asci conjugati possunt videri. Ascosporae petasosae, liberatae. Glucosum, (lente) fermentatur. Sucrosum, raffinosum, galactosum, trehalosum, maltosum, melezitosum, methyl $\alpha$-D-glucosidum, cellobiosum, salicinum, L-sorbosum, D-xylosum (lente et variabile), $D$ arabinosum (exigue et variabile), ethanolum (exigue), glycerolum (lente), ribitolum (lente), xylitolum (lente), mannitolum, glucitolum, acidum succinicum, acidum citricum, acidum malicum (exigue), glucono- $\delta$-lactonum, 2-ketogluconatum et $N$-acetylglucosaminum assimilantur at non inulinum (raro exigue), melibiosum, lactosum, amylum solubile, L-rhamnosum, L-arabinosum, D-ribosum methanolum, 1-propanolum, 2-propanolum, 1-butanolum, erythritolum, galactitolum, mesoinositolum, acidum lacticum, acidum gluconicum, glucosaminum, acetonum, ethyl acetas nec hexadecanum. Ethylaminum, lysinum et cadaverinum assimilantur at non natrium nitricum nec natrium nitrosum. Ad crescentiam vitaminae externae necessariae sunt. Augmentum in $37^{\circ} \mathrm{C}$. Habitatio in floribus et insectibus junctis Ipomoea et Hibiscus spp. in Australia et Hawaii. Typus stirps $\mathrm{UWO}(\mathrm{PS}) 95-602.1^{\mathrm{T}}\left(\mathrm{h}^{+}\right)$. Isotypus stirpes UWO(PS)91-893.2 ${ }^{\mathrm{I}}$ et UWO(PS)95-725.1 ${ }^{\mathrm{I}}\left(\mathrm{h}^{-}\right)$. In collectione zymotica Centraalbureau voor Schimmelcultures, Delphi Batavorum, sub no. CBS $8494^{\mathrm{T}}$ [= UWO(PS)95-602.1 ${ }^{\mathrm{T}}$ ], CBS $8495^{\mathrm{I}}$ [= UWO(PS)91-
893.2 ${ }^{\mathrm{I}}$ et $\mathrm{CBS} 8496^{\mathrm{I}}$ [ = UWO(PS)95-725.1 ${ }^{\mathrm{I}}$ ] depositae sunt.

\section{Description of Kodamaea anthophila sp. nov.}

Kodamaea anthophila (an.tho'phi.la. L. nom. fem. adj. anthophila flower-loving, referring to the flowers from which these yeasts were isolated).

In yeast extract $(0.5 \%)$ /glucose $(2 \%)$ broth after $3 \mathrm{~d}$ at $25^{\circ} \mathrm{C}$, the cells are ovoid to ellipsoidal, occur singly

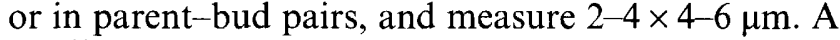
fragile matted pellicle is formed after $1-3 \mathrm{~d}$. On malt agar after 2 weeks at $17^{\circ} \mathrm{C}$, colonies are white to cream, smooth to rugose, often stellate or umbonate, glabrous to hairy, and butyrous to tough due to filamentous growth. Considerable variation occurs in colony morphology even amongst isolates from a single sample. In Dalmau plate cultures on cornmeal agar after 2 weeks, true septate hyphae are formed. After $1 \mathrm{~d}$ on glucose $(1 \%)$ /yeast extract $(0.01 \%)$ agar, mixed strains of complementary mating types give rise to one or more conjugation tubes. Conjugated pairs and zygotes are also present. Conjugation is often between an elongate cell and a more globose cell that becomes the ascus. After 2-3 d, mature asci are visible. Two to four hat-shaped ascospores are formed. Evanescence is frequently observed after $4 \mathrm{~d}$. Fermentation: in glucose, gas production begins after 3-5 $\mathrm{d}$ and a full tube of gas develops in 5-9 d. Assimilation of carbon compounds: sucrose, raffinose, galactose, trehalose, maltose, methyl $\alpha$-D-glucoside, cellobiose, salicin, Lsorbose, D-xylose (slow and variable), D-arabinose (weak and variable), ethanol (weak), glycerol (slow), ribitol (slow), xylitol (slow), mannitol, glucitol, succinic acid, citric acid, malic acid (weak), glucono- $\delta$ lactone, 2-ketogluconic acid and $N$-acetylglucosamine are assimilated; no growth occurs on inulin (rarely weak), melibiose, melezitose, lactose, starch, L-rhamnose, L-arabinose, methanol, ethanol, 2-propanol, 1butanol, erythritol, galactitol, meso-inositol, lactic acid, gluconic acid, D-glucosamine, acetone, ethyl acetate or hexadecane. Assimilation of nitrogen compounds: ethylamine, lysine and cadaverine positive; sodium nitrate and sodium nitrite negative. Growth in vitamin-free medium is negative. Growth in aminoacid-free medium is positive. Growth at $37^{\circ} \mathrm{C}$ is positive. Gelatin liquefaction and casein hydrolysis are negative. Lipolytic activity on Tween 80 agar is negative. Acid formation on chalk agar is negative. Growth on YM agar with $10 \%$ sodium chloride is positive; with $15 \%$ sodium chloride it is negative. Growth on $50 \%$ glucose/yeast extract agar is slow. Growth in the presence of $10 \mu \mathrm{g}$ cycloheximide $\mathrm{ml}^{-1}$ is positive; with $100 \mu \mathrm{g} \mathrm{ml}^{-1}$ it is negative. Growth in the presence of $8 \mu \mathrm{g}$ digitonin $\mathrm{ml}^{-1}$ at $25^{\circ} \mathrm{C}$ is negative. Production of starch-like compounds is negative. Urease activity is negative. Diazonium Blue B reaction is negative. The habitat is flowers of morning glories and Hibiscus species as well as associated beetles and Drosophila species. The type strain is UWO(PS)95$602.1^{\mathrm{T}}$. Its mating type was designated arbitrarily as 


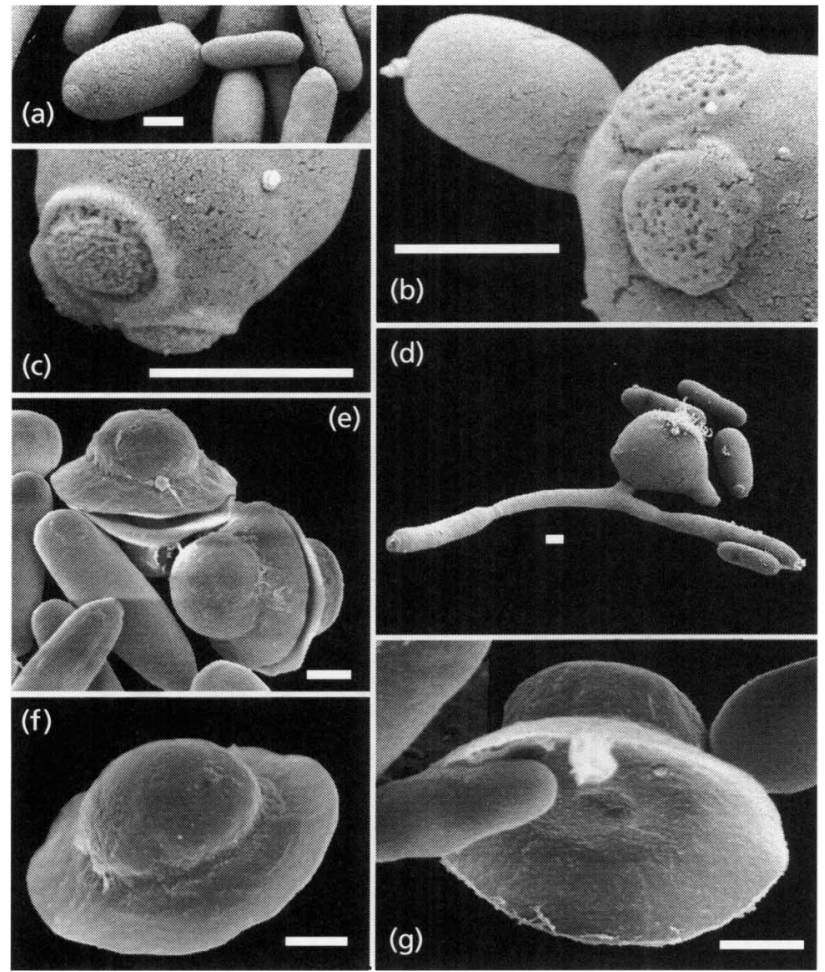

Fig. 1. Scanning electron micrographs of the sexual cycle of $K$. nitidulidarum. (a) Budding vegetative cells. (b, c) Detail of bud scars. (d) Ascus. (e-g) Ascospores liberated after Mureinase treatment. Bars, $1 \mu \mathrm{m}$.

$\mathrm{h}^{+}$. The designated isotypes, strains UWO(PS)91893.2 ${ }^{\mathrm{I}}$ and UWO(PS)95-725.1 ${ }^{\mathrm{I}}$, have mating type $\mathrm{h}^{-}$. They were isolated from flowers of beach morning glory in Hawaii, and flowers of morning glory and Hibiscus splendens in Australia, respectively. These strains have been deposited in the collection of the Yeast Division of the Centraalbureau voor Schimmelcultures, Delft, the Netherlands, as strains CBS $8494^{\mathrm{T}}$, CBS $8495^{\mathrm{I}}$ and CBS $8496^{\mathrm{I}}$, respectively.

\section{Ecology and habitat specificity}

The localities and host plants of the three new yeast species are listed in Tables 1,2 and 3. K. nitidulidarum and Candida restingae were isolated from the columnar cacti $P$. arrabidae and Cereus pernanbucensis in sand dune ecosystems in Brazil. Beetles that used the cactus flowers as breeding and feeding sites vector these yeast species (Rosa et al., 1994, 1995). K. nitidulidarum was isolated only from flowers and tunnels of the moth Sigelgaita sp. larvae in P. arrabidae. Larvae of Sigelgaita sp. penetrate cactus stems, sometimes entering through flowers. This could explain the occurrence of $K$. nitidulidarum in association with the moth tunnels as well as the flowers (Rosa et al., 1992). An unidentified nitidulid beetle was the principal vector of this species among the flowers (Rosa et al., 1994). Candida restingae was isolated from tunnels of Sigel-
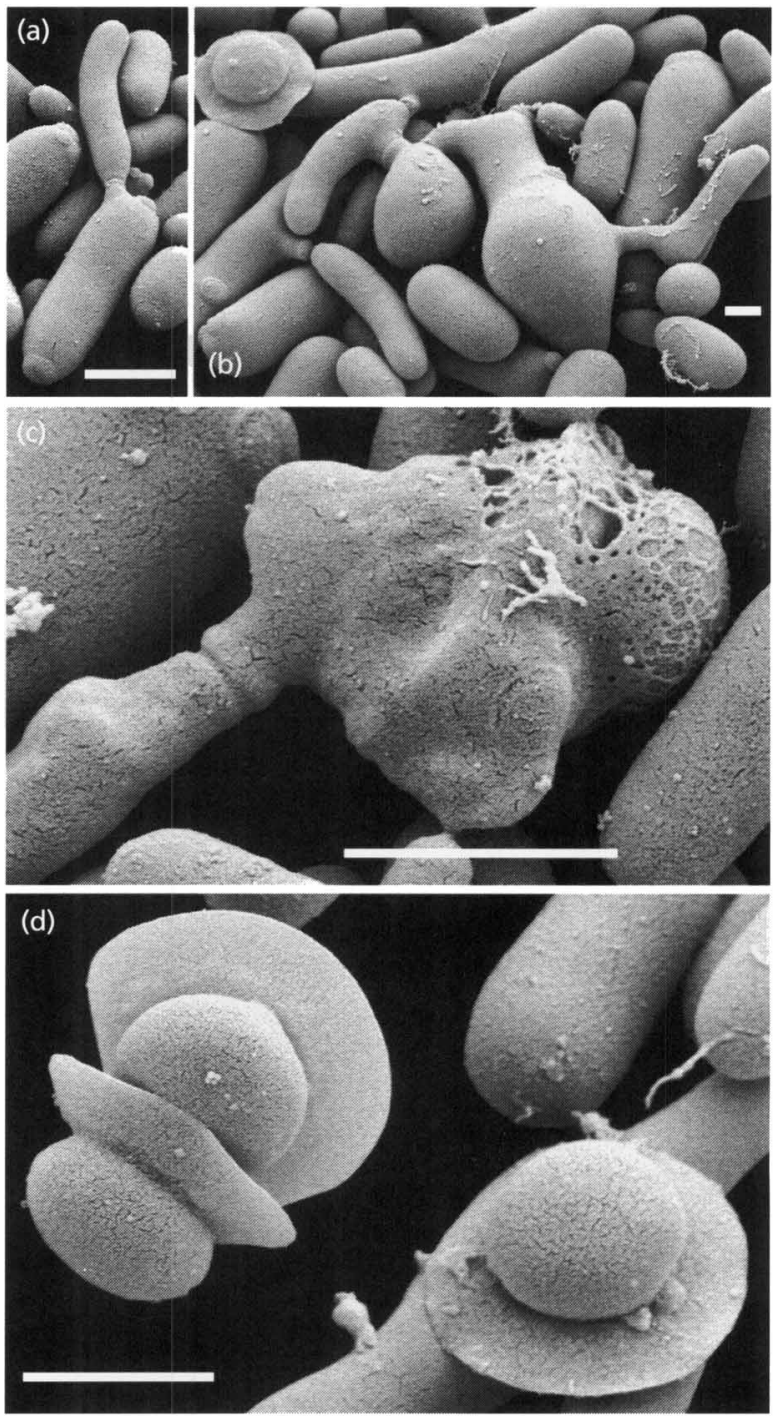

Fig. 2. Scanning electron micrographs of the vegetative cells and the sexual cycle of $K$. anthophila. (a) Budding vegetative cells. (b) Conjugating cells and vegetative cells. (c) Mature ascus in the process of deliquescing. (d) Hat-shaped ascospores liberated from asci. Bars, $2 \mu \mathrm{m}$.

gaita sp. and decaying flowers of $C$. pernanbucensis. Two beetle species were predominant in flowers of this cactus, namely Cyclocephala laminata (Scarabeidae) and the same unidentified species present in flowers of $P$. arrabidae (Rosa et al., 1995). Presumably, these beetles are the vectors of Candida restingae among flowers of the two cactus species.

$K$. anthophila was the dominant yeast species in flowers of Australian morning glories and Hibiscus as well as in Drosophila hibisci and a nitidulid beetle associated with them. It occurred in practically every one of over 400 samples examined. A single strain was isolated in beach morning glory (I. pes-caprae) in Hawaii, where over 100 morning glories (I. pes-caprae and Ipomoea acuminata) were examined (Lachance et al., 1989; and 

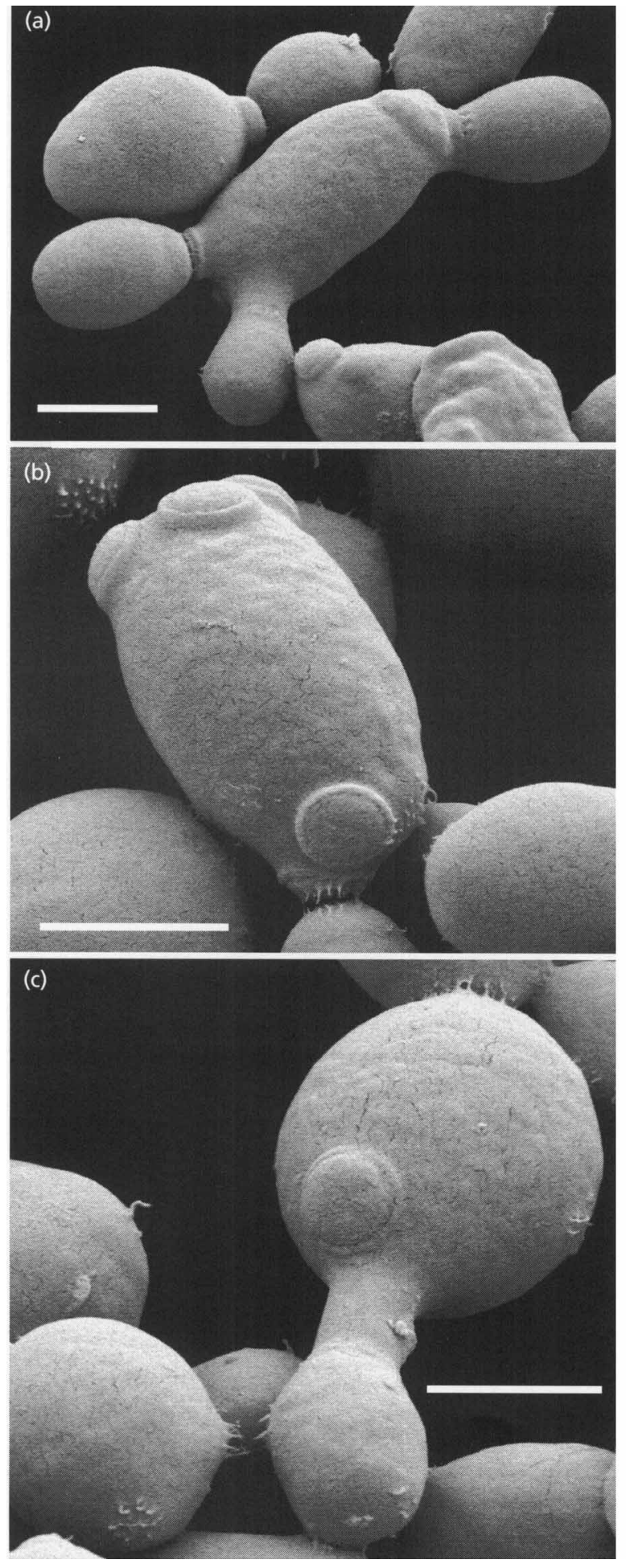

Fig. 3. Scanning electron micrographs of Candida restingae. (a) Budding cell. (b) Cell with bud scars. (c) A pedunculate bud. Bars, $2 \mu \mathrm{m}$.

later unpublished data). The ecology of yeast communities associated with these plants will be described elsewhere.

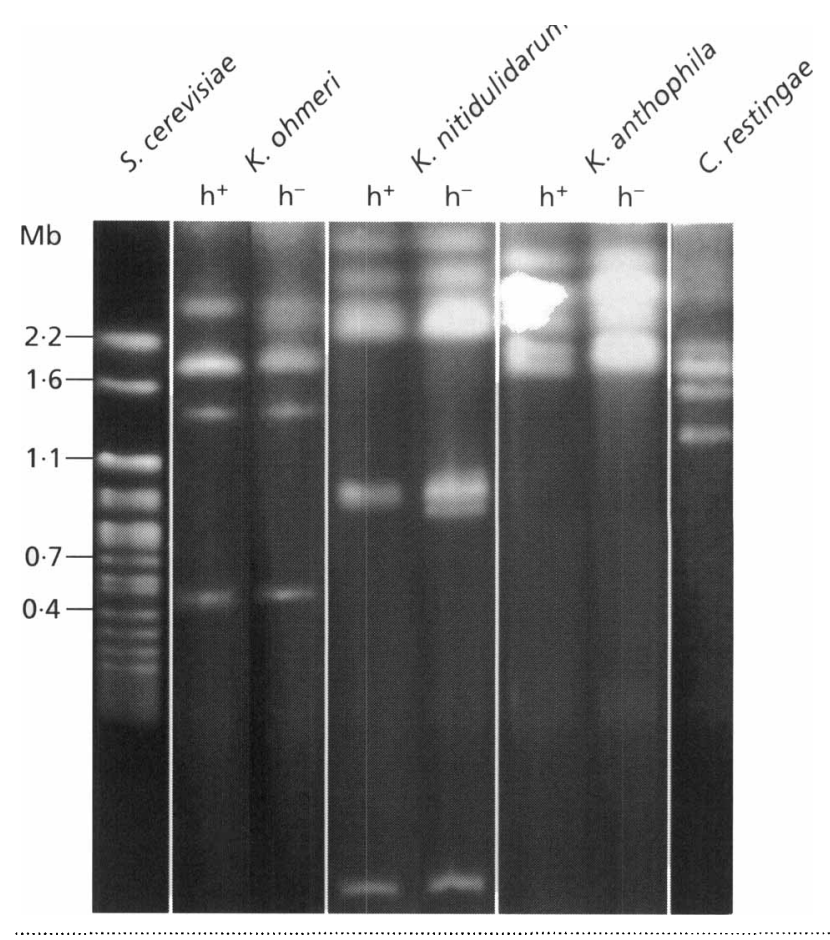

Fig. 4. Electrokaryotypes of selected strains of $K$. ohmeri, $K$. nitidulidarum, $K$. anthophila and Candida restingae. $S$. cerevisiae is the Bio-Rad standard. The mating types $\left(\mathrm{h}^{+}\right.$and $\left.\mathrm{h}^{-}\right)$ are indicated.

\section{Life cycles}

The life cycles of $K$. nitidulidarum and $K$. anthophila are nearly identical. The buds are formed multilaterally, but are generally concentrated near the apical region of the cells (Figs 1 and 2). Multiple scars are formed in both sides of the parent cells. Buds are normally elongate with a narrow base. Asci are formed after conjugation of two cells of compatible mating types. The asci of $K$. nitidulidarum are persistent and ascospores germinate inside the ascus. In $K$. anthophila the asci usually deliquesce (Fig. 2c) and the ascospores are liberated (Fig. 2d). The mating types of both species are distributed more or less equally, and both mating types were frequently isolated in the same sample. This suggests that these species are sexually active. Selfsporulating cultures have not been seen, however, which indicates that the vegetative phase is haploid in the natural habitat. Sexual reproduction was not observed in Candida restingae (Fig. 3). Budding is also multilateral and the buds tend to be ovoid to cylindrical. An elongate tube is sometimes observed between the parent cell and the bud (Fig. 3c).

\section{Electrophoretic karyotypes}

The electrophoretic karyotypes of Kodamaea species and Candida restingae were very distinct (Fig. 4). Strains of $K$. nitidulidarum produced a low-molecularsize band that may represent a plasmid. Most strains of 


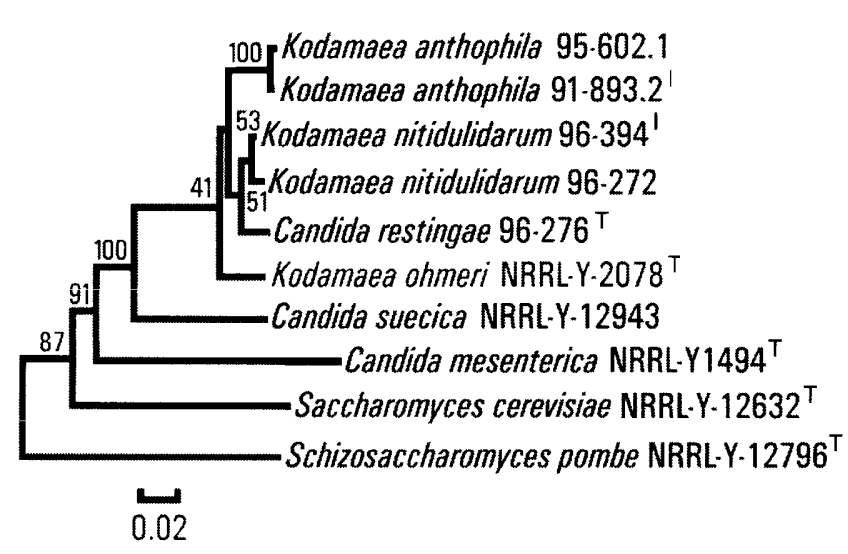

Fig. 5. Phylogeny of Kodamaea and related yeast species based on the D1/D2 variable domains of the large rDNA subunit. The tree was constructed by neighbour-joining analysis of aligned sequences. The numbers at the nodes indicate the percentage bootstrap values for 1000 iterations. The scale corresponds to $2 \%$ substitution.

this species exhibited killer activity against Candida glabrata Y-55 under standard conditions (Lachance et al., 1988). Whereas this might have suggested a link between killer ability and the putative plasmid, Candida restingae and $K$. anthophila also could exhibit the killer phenotype. $K$. ohmeri and Candida restingae have at least four chromosomes whereas $K$. anthophila and $K$. nitidulidarum have at least five. The electrokaryotypes are useful in distinguishing species from one another but strains of the same species had similar profiles.

\section{Evolutionary relatedness}

Analysis of the sequences of the D1/D2 regions of the large rDNA subunit showed that the Kodamaea species and Candida restingae form a homogeneous assemblage (Fig. 5). The two strains of $K$. nitidulidarum studied differed by five substitutions, which is at the high end of the range usually observed for members of the same species (Kurtzman \& Robnett, 1997). The cactus flower species were the most closely related. A close kinship between these species was expected as they share the same microhabitat in the Brazilian sand dunes and have not been found in any other plants in that ecosystem (Rosa et al., 1995). The strains of $K$. anthophila (three examined), although isolated in geographically distant locations, differed only by a single substitution.

The Kodamaea clade appears relatively recent, and $K$. ohmeri, by virtue of its less specialized ecology and its position in the rDNA phylogeny, may represent an ancestral form. This is consistent with the isolation of $K$. ohmeri from a number of different substrates, including food and clinical specimens (Kreger-van Rij, 1970), in contrast to the specificity of its sister taxa. However, a clear physiological specialization is not observed.

\section{Species identification and genus circumscription}

The morphology and physiological properties of Kodamaea species and Candida restingae exhibit a small amount of variation, and the identification based on such characters is tenuous, although not impossible. Mating reactions among the sexual species and rDNA sequencing provide good diagnoses. Below is an identification key based on the assimilation of a few carbon sources.

Key to Kodamaea species and Candida restingae

1. Melezitose assimilation rapid ............................... 2

Melezitose assimilation negative or delayed .......... 3

2. Trehalose and xylose assimilated $\rightarrow$ Candida restingae

Trehalose and xylose not assimilated $\rightarrow$ K. nitidulidarum

3. Xylitol assimilated $\rightarrow K$. anthophila

Xylitol not assimilated $\rightarrow$ K. ohmeri

Comparison of the species of the Kodamaea clade with other known yeasts indicated that identification strictly on the basis of physiology is not satisfactory. Specifically, separation from Candida guilliermondii, Candida melibiosica and Debaryomyces (syn. Schwanniomyces) occidentalis is difficult based on the nutritional tests normally administered in our laboratories, even though these species are unrelated to Kodamaea (Kurtzman \& Robnett, 1997). Other similar yeasts can be resolved on the basis of glucose fermentation and raffinose assimilation (positive in Kodamaea species and Candida restingae) and assimilation of lactose (negative in Kodamaea species and Candida restingae).

Expansion of the genus Kodamaea to three teleomorphic species warrants a modification of the generic definition given by Yamada et al. (1995b). The genus is now defined as follows. The genus belongs to the Saccharomycetaceae. Colonies are butyroid, membranous to tough, and may be furry or have a fringed border. Cells are globose, ellipsoid, ovoid to cylindrical. Budding is multilateral and may involve formation of a short protuberance. Pseudomycelium or true mycelium may be formed. Species in the genus are heterothallic, usually haploid, and occasionally diploid. Asci arise by transformation of diploid cells or by conjugation of independent cells. They may be evanescent or persistent, containing one to four ascospores. Ascospores are pileiform or globose and glabrous. Fermentation is present. Sucrose, raffinose, maltose, L-sorbose, mannitol, glucitol, citric acid, 2ketogluconate, L-lysine and cadaverine are assimilated. Growth occurs at $37^{\circ} \mathrm{C}$.

\section{ACKNOWLEDGEMENTS}

We acknowledge financial support from the Conselho Nacional de Desenvolvimento Científico e Tecnológico of Brazil-CNPq (Postdoctoral Fellowship to C.A.R. 
201125/96-0), the Natural Science and Engineering Research Council of Canada (M.-A. L.), the National Science Foundation International Programs (W.T.S.) and the Australian Research Council (J.S.F.B.). Permission to collect was obtained from the Queensland National Parks and Wildlife Service and the Queensland Forest Service. We thank Dr C. P. Kurztman for sending type cultures.

\section{REFERENCES}

Barnett, J. A., Payne, R.W. \& Yarrow, D. (1990). Yeasts: Characteristics and Identification. Cambridge: Cambridge University Press.

Billon-Grand, G. (1989). A new ascosporogenous genus, Yamadazyma gen. nov. Mycotaxon 35, 201-204.

Gardner, D. C., Heale, S. M., Stateva, L. I. \& Oliver, S. G. (1993). Treatment of yeast cells with wall lytic enzymes is not required to prepare chromosomes for pulsed-field gel analysis. Yeast 9 , 1053-1055.

Kreger-van Rij, N. J. W. (1970). Pichia Hansen. In The Yeasts, a Taxonomic Study, 2nd edn, pp. 455-554. Edited by J. Lodder. Amsterdam: North-Holland Publishing.

Kreger-van Rij, N. J. W. (1984). The Yeasts, a Taxonomic Study, 3rd edn. Amsterdam: Elsevier.

Kurtzman, C. P. (1984). Pichia Hansen. In The Yeasts, a Taxonomic Study, 3rd edn, pp. 295-378. Edited by N. J. W. Kreger-van Rij. Amsterdam: Elsevier.

Kurtzman, C. P. \& Robnett, C. J. (1997). Identification of clinically important ascomycetous yeasts based on nucleotide divergence in the $5^{\prime}$ end of the large subunit (26S) ribosomal gene. $J$ Clin Microbiol 35, 1216-1223.

Lachance, M. A. (1990). Ribosomal DNA spacer variation in the cactophilic yeast Clavispora opuntiae. Mol Biol Evol 7, 178-193.

Lachance, M. A., Starmer, W. T. \& Phaff, H. J. (1988). Identification of yeasts found in decaying cactus tissue. Can J Microbiol 34, 1025-1036.
Lachance, M. A., Starmer, W. T. \& Bowles, J. M. (1989). The yeast community of morning glory and associated drosophilids in a Hawaiian Kipuka. Yeast 5, S501-S504.

O'Donnell, K. (1993). Fusarium and its near relatives. In The Fungal Holomorph: Mitotic, Meiotic and Pleomorphic Speciation in Fungal Systematics, pp. 225-233. Edited by D. R. Reynolds \& J. W. Taylor. Wallingford: CAB International.

Rosa, C. A., Hagler, A. N., Mendonça-Hagler, L. C., Morais, P. B., Gomes, N. C. M. \& Monteiro, R. F. (1992). Clavispora opuntiae and other yeasts associated with the moth Sigelgaita sp. in the cactus Pilosocereus arrabidae of Rio de Janeiro, Brazil. Antonie Leeuwenhoek 62, 267-272.

Rosa, C. A., Morais, P. B., Hagler, A. N., Mendonça-Hagler, L. C. \& Monteiro, R. F. (1994). Yeast communities of the cactus Pilosocereus arrabidae and associated insects in the Sandy Coastal Plains of Southeastern Brazil. Antonie Leeuwenhoek 65, 55-62.

Rosa, C. A., Morais, P. B., Santos, S. R., Peres Neto, P., Hagler, A. N. \& Mendonça-Hagler, L. C. (1995). Yeast communities associated with different plant resources in the Sandy Coastal Plains of Southeastern Brazil. Mycol Res 99, 1047-1054.

Thompson, J. D., Higgins, D. G. \& Gibson, T. J. (1994). CLUSTAL $\mathrm{W}$ : improving the sensitivity of progressive multiple sequence alignment through sequence weighting, position-specific gap penalties and weight matrix choice. Nucleic Acids Res 22, 4673-4680.

van der Walt, J. P. \& Yarrow, D. (1984). Methods for the isolation, maintenance, classification and identification of yeasts. In The Yeasts, a Taxonomic Study, 3rd edn, pp. 45-104. Edited by N. J. W. Kreger-van Rij. Amsterdam: Elsevier.

Yamada, Y., Suzuki, T., Matsuda, M. \& Mikata, K. (1995a). The phylogenetic relationships of the Q9-equipped, hat-shaped ascospore-forming species of the genus Yamadazyma BillonGrand (Saccharomycetaceae) based on the partial sequences of 18 S and 26S rRNAs. Biosci Biotechnol Biochem 59, 445-450.

Yamada, Y., Suzuki, T., Matsuda, M. \& Mikata, K. (1995b). The phylogeny of Yamadazyma ohmeri (Etchells et Bell) BillonGrand based on the partial sequences of $18 \mathrm{~S}$ and 26S rRNAs: the proposal of Kodamaea gen. nov. (Saccharomycetaceae). Biosci Biotechnol Biochem 59, 1172-1174. 